\title{
Contribution of Lakshmibai National Institute of Physical Education Gwalior in the Development of Teaching Learning Process in Physical Education
}

\author{
Dr. Rajesh Dhauta \\ Assistant Professor, Amity University
}

\begin{abstract}
Objective of the study to explore the its contribution in the development of teaching and learning process in physical education in India. The academics and professional guidance provided by the Institute to various government, quasi government and private organizations. After the independence it was felt to improve standard of Physical Education in India. Keeping in view of the importance of Physical Education in the growth and development of human being, Government of India showed its due concern. The Central Advisory Board of Physical Education and Recreation and University Education Commission, under the chairmanship of Dr. S. Radhakrishnan, recommended the introduction of degree course in physical education to improve the quality of teachers of physical education and to serve as model for the colleges of physical education in the country. For the purpose of the study 100 registered students of B.P.Ed, M.P.Ed, Students of Diploma courses, M.Phil and PhD Scholars were selected randomly, whereas 46 faculty members and 500 registered alumni were selected including Principal, Dean, Ex-Director, Vice-Chancellor, Ex-faculty member of Lakshmibai National University of Physical Education, Gwalior, (M.P). On the basis of the review of related literature, expert opinion in the field of physical education, sports psychology, social science and scholar's own understanding the variables selected for the study was: Contribution of LNUPE in development of teaching learning process in physical education.The opinionnaire was personally discussed with and sent to the subjects. Primary data was collected from Students, Faculty, Alumni, Principals, Deans, Directors and Vice-Chancellors and secondary data from official records, annual reports and published material etc. The analysis of data using Chisquare clearly reveals that LNUPE has been successful in performing yeoman service above mentioned variable. It was hypothesised that the association among various groups of respondents on teaching learning and evaluation procedure adopted by LNUPE, Gwalior will be alike was accepted because LNUPE provide latest programmes in physical education, ensure quality among students, makes effort for the professional development of the students and staff by providing them study leave and leaves for attending national and international seminars and conferences.
\end{abstract}

Keywords: Physical Education, Opinionnaire, Alumni

\section{Introduction}

After the independence it was felt to improve standard of Physical Education in India. Keeping in view of the importance of Physical Education in the growth and development of human being, Government of India showed its due concern. The Central Advisory Board of Physical Education and Recreation and University Education Commission, under the chairmanship of Dr. S. Radhakrishnan, recommended the introduction of degree course in physical education to improve the quality of teachers of physical education and to serve as model for the colleges of physical education in the country. On August 17, 1957 the College made its beginning in the old barracks like structure in the Mela Ground with less than half of a dozen teachers and twenty six students. Within six weeks the college shifted to its present location covering 150 acres of picturesque land which was the old race course and polo ground of the Scindias which was gifted to the College. To start with college, offered a three years degree course leading to Bachelor's Degree in Physical Education so that teacher-trainees could acquire superior sports skills as well as width and adequate depth of knowledge concerning philosophy, purpose and methodology of physical education, which are impossible to achieve in one academic year.

\section{Procedure and Methodology}

The procedures adopted for the present study are being explained through varied dimensions inclusive of sources of data, tools used for data collection, development of opinionnaire, administration of the test for collection of the data and statistical analysis.

Selection of Respondents: For the purpose of the study following target population were selected as subjects of the study:

\section{Sampling Frame:}

- Registered students and Scholars of the Lakshmibai National University of Physical Education, Gwalior 100.

- Faculty members of Lakshmibai National University of Physical Education, Gwalior 46.

- Registered Alumni, Principal, Dean, Ex-Director, ViceChancellor, Ex- faculty memberof Lakshmibai National University of Physical Education, Gwalior 500.

Sampling Technique: Stratified random sampling technique was used, ensuring the representation of sample.

Selection of Variables: On the basis of the review of the related literature, expert opinion in the field of physical education, sports psychology, social science and scholar's own understanding curriculum design and development was selected as a variable for the study.

Selection of Tools Employed: A self constructed and developed opinionnaire was established to study the 


\section{International Journal of Science and Research (IJSR) \\ ISSN (Online): 2319-7064}

Index Copernicus Value (2013): 6.14 | Impact Factor (2015): 6.391

Contribution of LNIPE, Gwalior in the Curriculum Design and Development in Physical Education in India.

Designing the Opinionnaire: The opinionnaire was framed and constructed by inviting the initial pool of items from various sources relevant to the study. Such sources included literature review, views of available experts, comments and suggestions by commoners and general observations made during the personal and professional interactions by the investigator during the preparatory stages of study. Additional items were continued to be pooled into the draft in the process of framing and reframing of statements. Out of the collected items in pool, the opinionnaire was constructed in consultation with the advisors, experts and the professional colleagues.

Thirty four statements were prepared on 5 point Likert scale to determine the Contribution of LNIPE, Gwalior in the Curriculum Design and Development in Physical Education in India. The statements were followed by 5 options labeled from strongly agree to strongly disagree. The respondents were requested to tick mark one option that best reflects the degree of agreement or disagreement with each statement.

\section{Construction of the Opinionnaire}

Establishing Content Validity: The content validity was established by administering the following steps:

Initial Writing: The opinionnaire was constructed in relation to specific objectives of the study. A pool of items for opinionnaire was created based on reference from literature review and professional expertise from areas of sports management, psychology, sociology, physical education and sports.

Focus Group Review: Each statement framed was thoroughly evaluated by group of experts in the field of sports psychology, sports sociology and physical education. They were presented all the statements in the form of question along with the objectives of the study. Ambiguities in the statements were discussed with the help of consecutive discussion by various set of audience. The process helped to eliminate unwanted words, sentences, and ambiguity in the meaning of the statements from of the pool of available items.

Try Out:After having formulated the opinionnaire in an organised manner, the next step was implemented for 'Trial Run' of the draft opinionnaire. The purpose of the trial run, was to assess whether the meaning of all statements given in the opinionnaire was clear and adequate to obtain the desired information.

Rewriting: On the basis of the received suggestions and information laid down by the respondents of the trial run, necessary changes were made in the construction of opinionnaire and it was finally formulated consisting of 34 statements after the approval of the supervisor.

Second Trial Run: After making amendments according to the suggestions received, the second draft was prepared after thorough analysis and reviews. Desired changes were brought in the opinionnaire followed by its second run on the 30 subjects. At this stage, an average time of 10 minutes was recorded for duly fill-in the opinionnaire.

Final Writing: On the basis of the suggestions received, 34 questions were drafted. The opinionire was considered to be having content validity and was all set to be tested for consistency of the tool. It was essential that the subjects should understand the question for which it was intended. Therefore, on the basis of the received suggestions, minor amendments were made in the final copy of opinionnaire.

Data Collection and Administration of the Opinionnaire: The opinionnaire was personally discussed with and sent to the subjects. The objectives of the study were briefed, clear and short instructions were given regarding the procedure of filling the opinionnaire. Prior appointment was taken from the subjects according to their availability of time. They were requested to immediately tick the response that comes into their mind at first thought. They were asked to respond between the scales of "Highly agree" to "Not agree".

Statistical Procedure: Keeping in view the objectives of the study, the data was collected by opinionnaire for the purpose of the study, both primary and secondary data. Primary data was collected from Students, Faculty, Aluminise, Principals, Deans, Directors and Vice-Chancellors and secondary data from official records, Annual Reports and Published material etc. This information was tabulated item wise in the form of frequencies (responses), converted into percentage and data was analysed using Chi Square in respect of statements asking for alternate response in the opinionnaire.

\section{Analysis of Data and Findings of Study}

To gather information on Contribution of LNIPE, Gwalior in Curriculum Design and Development in Physical Education in India. Total 800 students, alumni and teachers were asked to send their responses on given opinionnaire out of which only 650 students, alumni and teachers had replied back. Responses pertaining to each of the statement were analyzed and have been presented in terms of the total responses in percent and chi-square value. The findings of the present study are presented in the following Tables -

\section{Teaching Learning and Evaluation}

Table 1

Statement No. 1 (a) LNUPE provides latest programmes in Physical Education

\begin{tabular}{|c|c|c|c|c|c|}
\hline S. No & Response & Frequency & Percentage & df & $\mathbf{X}^{2}$ \\
\hline 1 & Strongly Agree & 278 & 42.8 & \multirow{6}{*}{04} & \multirow{6}{*}{$686.8 *$} \\
\hline 2 & Agree & 306 & 47.1 & & \\
\hline 3 & Undecided & 30 & 4.6 & & \\
\hline 4 & Disagree & 36 & 5.5 & & \\
\hline \multirow[t]{2}{*}{5} & Strongly Disagree & - & - & & \\
\hline & Total & 650 & 100.0 & & \\
\hline
\end{tabular}

Volume 5 Issue 5, May 2016 www.ijsr.net 


\section{International Journal of Science and Research (IJSR) \\ ISSN (Online): 2319-7064}

Index Copernicus Value (2013): 6.14 | Impact Factor (2015): 6.391

The analysis of data in table 6 clearly shows that the value of $\mathrm{X}^{2}$ i.e. 686.8 is significant at 0.05 level. The value of $\mathrm{X}^{2}$ is found to be significantly higher than the table value of 9.49 with 4 degree of freedom. The table further reveals that the responses of 650 respondents for different points of Likert Scale are - Strongly Agree 42.8\%, Agreed 47.1\%, Undecided $4.3 \%$, Disagree $5.5 \%$. The data pertaining to above question is graphically presented using pie diagram in figure 1.

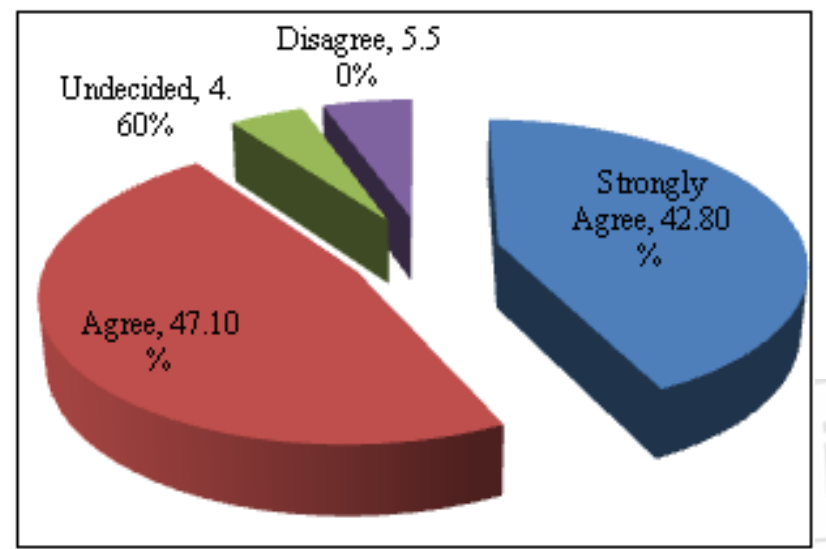

Figure-1

Table 2

Statement No. 1 (b): LNUPE provide latest programme in Health and Fitness.

\begin{tabular}{|c|c|c|c|c|c|}
\hline S. No & Response & Frequency & Percentage & df & \multicolumn{1}{|c|}{$\mathbf{X}^{\mathbf{2}}$} \\
\hline 1 & Strongly Agree & 254 & 39.1 & & \\
\hline 2 & Agree & 284 & 43.7 & & \\
\hline 3 & Undecided & 66 & 10.2 & \multirow{3}{*}{04} & \multirow{5}{*}{$513.3^{*}$} \\
\hline 4 & Disagree & 41 & 6.3 & & \\
\hline 5 & Strongly Disagree & 5 & .8 & & \\
\hline & Total & 650 & 100.0 & & \\
\hline
\end{tabular}

$*$ significant at 0.05 level of significance $\mathrm{X}^{2}(4)(0.05)=9.49$

From the above table 2 it can be clearly inferred that the value of $\mathrm{X}^{2}$ i.e. 513.3 is significant at 0.05 level. The value of $\mathrm{X}^{2}$ is found to be significantly higher than the table value of 9.49 with 4 degree of freedom. The table further reveals that the responses of 650 respondents for different points of Likert Scale are - Strongly Agree 39.1\%, Agreed 43.7\%, Undecided $10.2 \%$, Disagree $6.3 \%$ and Strongly Disagree $.8 \%$ The data pertaining to above question is graphically presented using pie diagram in figure 2.

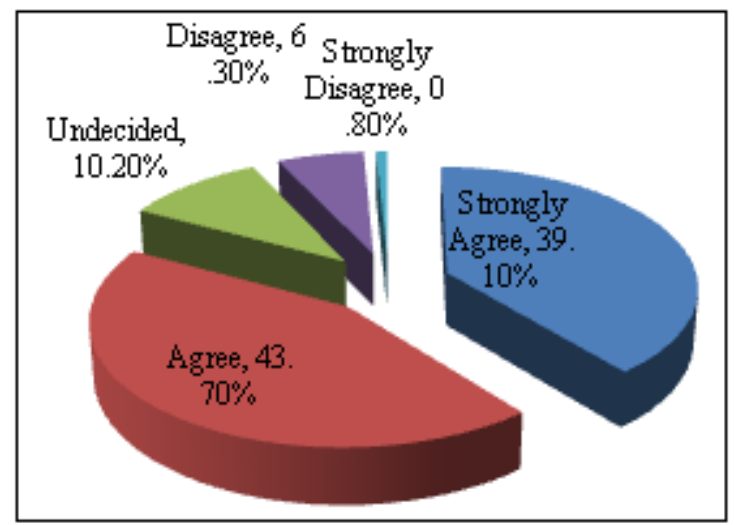

Figure 2
Table 3

Statement No.1 (c) LNUPE provide latest programme in Science of Sports Coaching.

\begin{tabular}{|c|c|c|c|c|c|}
\hline S. No & Response & Frequency & Percentage & df & $\mathbf{X}^{\mathbf{2}}$ \\
\hline 1 & Strongly Agree & 205 & 31.5 & & \\
\cline { 1 - 4 } 2 & Agree & 301 & 46.3 & & \\
\cline { 1 - 4 } 3 & Undecided & 101 & 15.5 & & \multirow{3}{*}{$454.4^{*}$} \\
\hline 4 & Disagree & 32 & 4.9 & & \\
\hline 5 & Strongly Disagree & 11 & 1.7 & & \\
\hline & Total & 650 & 100.0 & & \\
\hline
\end{tabular}

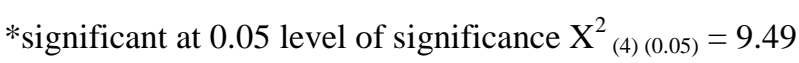

The result of the application of Chi-square, the value of $\mathrm{X}^{2}$ i.e. 454.4 is significant at 0.05 level. The value of $\mathrm{X}^{2}$ is found to be significantly higher than the table value of 9.49 with 4 degree of freedom. The table further reveals that the responses of 650 respondents for different points of Likert Scale are - Strongly Agree 31.5\%, Agreed 46.3\%, Undecided $15.5 \%$, Disagree $4.9 \%$ and Strongly Disagree $1.7 \%$ The data pertaining to above question is graphically presented using pie diagram in figure 3 .

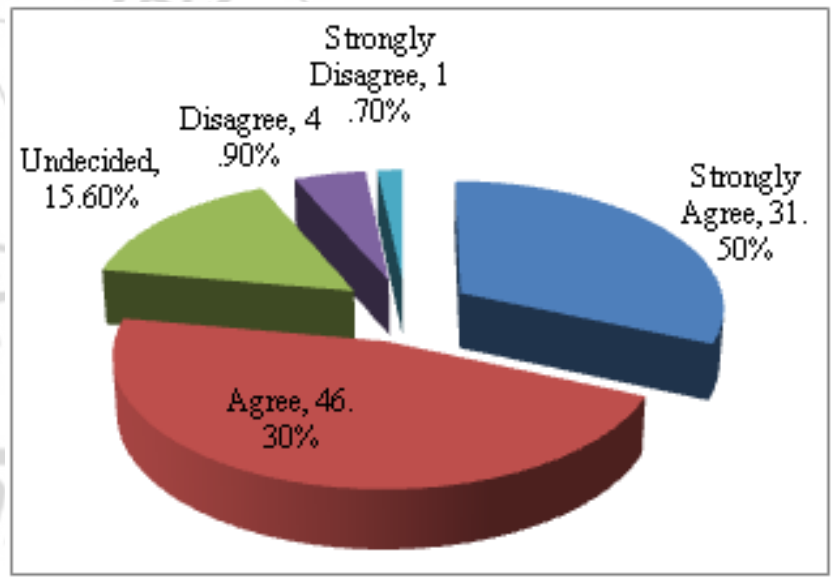

Figure 3

Table 4

Statement No. 2.LNUPE promotes and ensure equality in students from disadvantaged community, women, and different able, economically weaker sections and sports personnel.

\begin{tabular}{|c|c|c|c|c|c|}
\hline S. No & Response & Frequency & Percentage & df & $\mathbf{X}^{\mathbf{2}}$ \\
\hline 1 & Strongly Agree & 142 & 21.8 & & \\
\hline 2 & Agree & 319 & 49.1 & & \\
\hline 3 & Undecided & 131 & 20.2 & \multirow{3}{*}{04} & \multirow{4}{*}{$435.1^{*}$} \\
\hline 4 & Disagree & 47 & 7.2 & & \\
\hline 5 & Strongly Disagree & 11 & 1.7 & & \\
\hline & Total & 650 & 100.0 & & \\
\hline
\end{tabular}

*significant at 0.05 level of significance $\mathrm{X}^{2}(4)(0.05)=9.49$

The analysis of data in table 4 clearly reveals that the value of $\mathrm{X}^{2}$ i.e. 435.1 is significant at 0.05 level. The value of $\mathrm{X}^{2}$ is found to be significantly higher than the table value of 9.49 with 4 degree of freedom. The table further reveals that the responses of 650 respondents for different points of Likert Scale are - Strongly Agree 21.8\%, Agreed 49.1\%, Undecided $20.2 \%$, Disagree $7.2 \%$ and Strongly Disagree $1.7 \%$ The data pertaining to above question is graphically presented using pie diagram in figure 4 . 


\section{International Journal of Science and Research (IJSR) \\ ISSN (Online): 2319-7064}

Index Copernicus Value (2013): 6.14 | Impact Factor (2015): 6.391

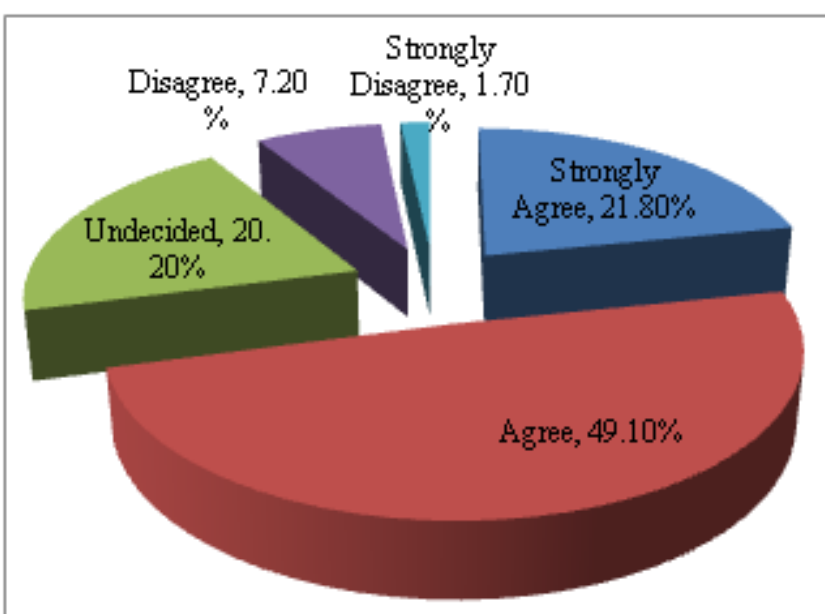

Figure 4

Table 5

Statement No. 3.LNUPE uses standard procedure for assessing the teaching methodology according to the need of the students.

\begin{tabular}{|c|c|c|c|c|c|}
\hline S. No & Response & Frequency & Percentage & $d f$ & $X^{2}$ \\
\hline 1 & Strongly Agree & 198 & 30.5 & & \\
\cline { 1 - 4 } 2 & Agree & 315 & 48.5 & & \\
\hline 3 & Undecided & 74 & 11.4 & \multirow{3}{*}{04} & \multirow{2}{*}{$478.6^{*}$} \\
\hline 4 & Disagree & 52 & 8.0 & & \\
\cline { 1 - 4 } 5 & Strongly Disagree & 11 & 1.7 & & \\
\hline & Total & 650 & 100.0 & & \\
\hline
\end{tabular}

*significant at 0.05 level of significance $\mathrm{X}^{2}{ }_{(4)(0.05)}=9.49$

The analysis of data in table 5 clearly shows that the value of $\mathrm{X}^{2}$ i.e. 478.6is significant at 0.05 level. The value of $\mathrm{X}^{2}$ is found to be significantly higher than the table value of 9.49 with 4 degree of freedom.The table further reveals that the responses of 650 respondents for different points of Likert Scale are - Strongly Agree 30.5\%, Agreed 48.5\%, Undecided $11.4 \%$, Disagree $8 \%$ and Strongly Disagree $1.7 \%$ The data pertaining to above question is graphically presented using pie diagram in figure 5.

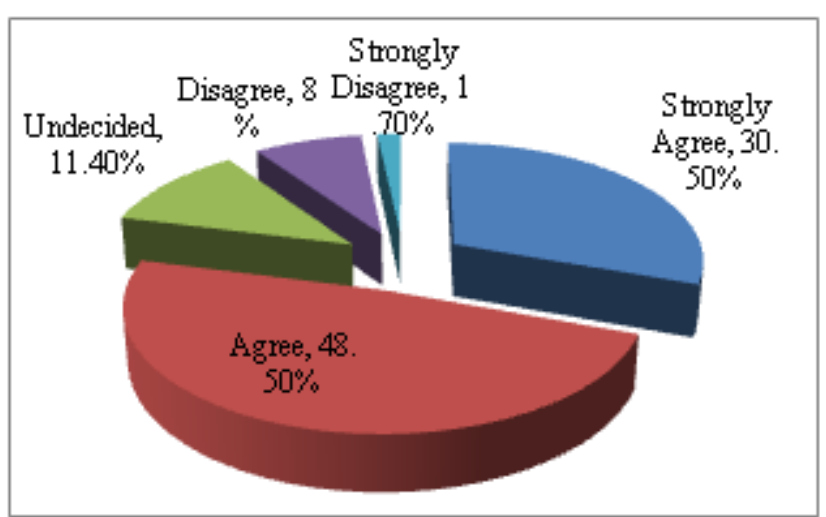

Figure-5

Table 6:

Statement No. 4: LNUPE adopts strategies to identify slow and advance learner

\begin{tabular}{|c|c|c|c|c|c|}
\hline S. No & Response & Frequency & Percentage & df & $\mathrm{X}^{2}$ \\
\hline 1 & Strongly Agree & 125 & 19.2 & & \\
\cline { 1 - 4 } 2 & Agree & 320 & 49.2 & & \\
\cline { 1 - 4 } 3 & Undecided & 109 & 16.8 & \multirow{3}{*}{04} & \multirow{3}{*}{$394.6^{*}$} \\
\hline 4 & Disagree & 77 & 11.8 & & \\
\cline { 1 - 4 } 5 & Strongly Disagree & 19 & 2.9 & & \\
\hline & Total & 650 & 100.0 & & \\
\hline
\end{tabular}

*significant at 0.05 level of significance $\mathrm{X}^{2}(4)(0.05)=9.49$

From the above table 6 it is clear that the value of $\mathrm{X}^{2}$ i.e.394.6is significant at 0.05 level. The value of $X^{2}$ is found to be significantly higher than the table value of 9.49 with 4 degree of freedom.The table further reveals that the responses of 650 respondents for different points of Likert Scale are - Strongly Agree 19.2\%, Agreed 49.2\%, Undecided $16.8 \%$, Disagree $11.8 \%$ and Strongly Disagree $2.9 \%$.The data pertaining to above question is graphically presented using pie diagram in figure 6 .

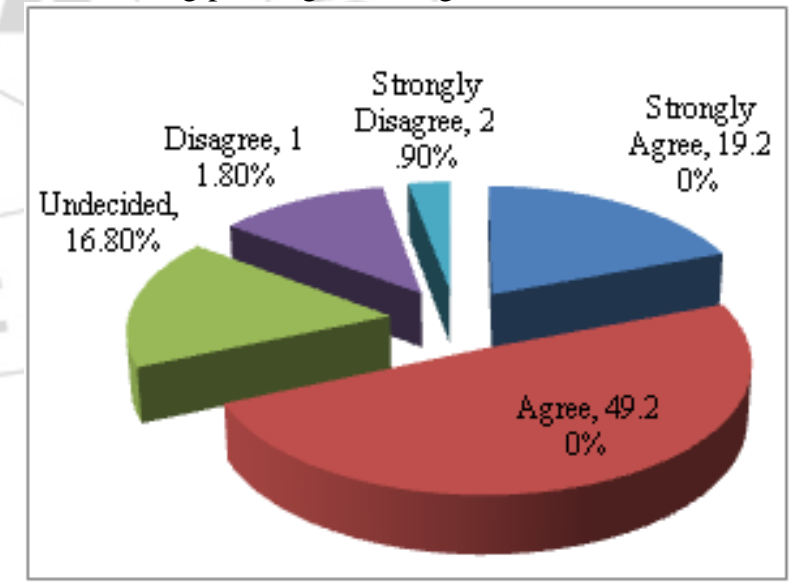

Figure-6

Table 7: Statement No. 5.LNUPE makes effort for the professional development of the student and faculty by providing them study leave, deputation to national/international conferences, seminars and training programmes

\begin{tabular}{|c|c|c|c|c|c|}
\hline S. No & Response & Frequency & Percentage & $d f$ & $X^{2}$ \\
\hline 1 & Strongly Agree & 251 & 38.6 & \multirow{6}{*}{04} & \multirow{6}{*}{$454.8^{*}$} \\
\hline 2 & Agree & 271 & 41.7 & & \\
\hline 3 & Undecided & 75 & 11.5 & & \\
\hline 4 & Disagree & 35 & 5.4 & & \\
\hline \multirow[t]{2}{*}{5} & Strongly Disagree & 18 & 2.8 & & \\
\hline & Total & 650 & 100.0 & & \\
\hline
\end{tabular}

*significant at 0.05 level of significance $\mathrm{X}^{2}(4)(0.05)=9.49$ 


\section{International Journal of Science and Research (IJSR) \\ ISSN (Online): 2319-7064}

Index Copernicus Value (2013): 6.14 | Impact Factor (2015): 6.391

The analysis of data in table 7 clearly shows that the value of $\mathrm{X}^{2}$ i.e. $454.8 \mathrm{is}$ significant at 0.05 level. The value of $\mathrm{X}^{2}$ is found to be significantly higher than the table value of 9.49 with 4 degree of freedom. The table further reveals that the responses of 650 respondents for different points of Likert Scale are - Strongly Agree 38.6\%, Agreed 41.7\%, Undecided $11.5 \%$, Disagree $5.4 \%$ and Strongly Disagree $2.8 \%$ The data pertaining to above question is graphically presented using pie diagram in figure 7.
[4] Anderson, David F. (1978)“A Synthesis of the Canadian Federal Government Policies in Amateur Sports, Fitness and Recreation Since 1961," University of Northern Colorado,Journal of Sport History, 1978.

[5] Dhauta, Rajesh, "Contribution of LNUPE Gwalior in Curriculum Design and Development in Physical Education in India" Indian Journal of Physical Education Sports Medicine and Exercise Science, Volume 13, Issue 2, 2013

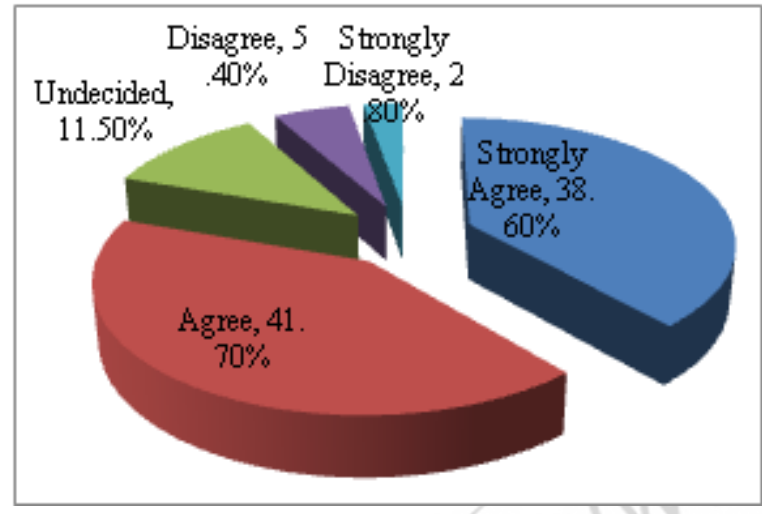

Figure-7

\section{Discussion of Findings}

The analysis of data using Chi- square clearly reveals that LNUPE has been successful in performing yeoman service in all the above areas and has provided good leadership to all the colleges of Physical Education and Departments of Physical Education established in different Universities in India. Since LNUPE is the only University of Physical Education which is fully funded by the Ministry of Youth and Sports, it fulfills all the functions in connection with teaching learning and evaluation procedure. Other Institutions and Teaching Department of different Universities fully recognize the help and guidance provided by LNUPE in this regard. It was hypothesised that the association among various groups of respondents on teaching learning and evaluation of procedure adopted by LNUPE, Gwalior will be alike was accepted because LNUPE provide latest programmes in physical education, ensure quality among students, makes effort for the professional development of the students and staff by providing them study leave and leaves for attending national and international seminars and conferences.

\section{References}

[1] Bucher, A. Charles, "Foundation of Physical Education" $3^{\text {rd }}$ ed. St. Louis: The C.V. Mosby Company, 1960

[2] Domenica, D.Survey of Higher Education Faculty Development Practices and Professional Needs of Physical Educators at Selected careers Stages. New York University, 1986.

[3] Ahrabi-Fard, Iradge, Implications of the Original Teachings of Islam for PhysicalEducationandSport,Universityof Minnesota, Journal of Sport History, 1978 